\title{
The role of furniture in exposure to non-ionizing radiation in a residential apartment
}

\author{
Vasil Bilero \\ Department of Physics, Faculty of Natural Sciences, University of Gjirokastra, Gjirokastra, Albania; vasilbilero@yahoo.com
}

Received 15 February 2012; revised 19 March 2012; accepted 29 March 2012

\begin{abstract}
This article concerns the sources of non-ionizing radiation in a normal inhabited environment. Measurements show that residents are exposed to non-ionizing radiation in levels both below and above the European normative. Excess is present due to the fact that, producers of electronic equipment and appliances, those who use them, as well as those involved in the construction of housing, have insufficient acquaintance with non-ionizing radiation. Producers are advised to increase the coefficient of safety towards non-ionizing radiation by renewing technology. Users are advised to operate apparatus with the lowest possible power, to minimise time exposed to sources, to maximise the distance from them and to renew their appliances. Construction workers should take non-ionizing radiation more into consideration when furnishing of houses.
\end{abstract}

Keywords: Role; Furniture; Non-Lonizing; Radiation; Residential; Apartment

\section{INTRODUCTION}

Rapid development of science and technology is associated with a necessary contaminant: non-ionizing radiation.

This article treats the following areas: the wave nature of non-ionizing radiation, its spread in the electromagnetic spectrum, the physical quantities and units by which non-ionizing radiation can be measured [1-6]. An attempt is made to supply the public with essential and sufficient knowledge of non-ionizing radiation present in their homes (including internal and external types of sources, models, their power as well as invisible sources). With the results of measurements of non-ionizing radiation within their dwelling places, they might judge to act and to suggest to people who deal with projecting and furnishing the houses, with frequent renovation of technology in order to reduce the non ionizing radiation and to avoid as much as possible the exposure to it $[3,4,6,7]$.

\section{MATERIALS AND METHODS}

1) Materials that are used: field meters up to $300 \mathrm{MHz}$ and up to $3 \mathrm{GHz}$, an inhabited apartment available in the city of Gjirokastër.

2) Experimental method is applied by direct measurement.

\section{THE WAVE NATURE OF NON-IONIZING RADIATION}

(For more see 8) [1-6].

\section{SOME PHYSICAL QUANTITIES AND THEIR UNITS BY WHICH NON-IONIZING RADIATION IS VALUED}

(For more see 8) $[8,9]$.

\section{SOURCES OF NON-IONIZING RADIATION IN A NORMAL HABITATION}

A normal inhabited apartment is selected for this work (AP.3 Figure 1).

\section{MEASUREMENTS OF NON-IONIZING RADIATION $[7,8,10]$}

The measurements are done in Apartment 3 of the Block behind the Sports Palace, "18 Shtatori" neighbourhood, Gjirokastër, Albania.

\subsection{Measurements}

1) The level of non-ionizing radiation of external sources of high frequencies is $\mathrm{B}=0.059 \mu \mathrm{T}$.

2) The level of radiation of sources of internal environment is as in Tables $\mathbf{1}$ and 2.

\subsection{Comments about Measurements}

Table 1, the measurements 12 and 13 show the differ- 


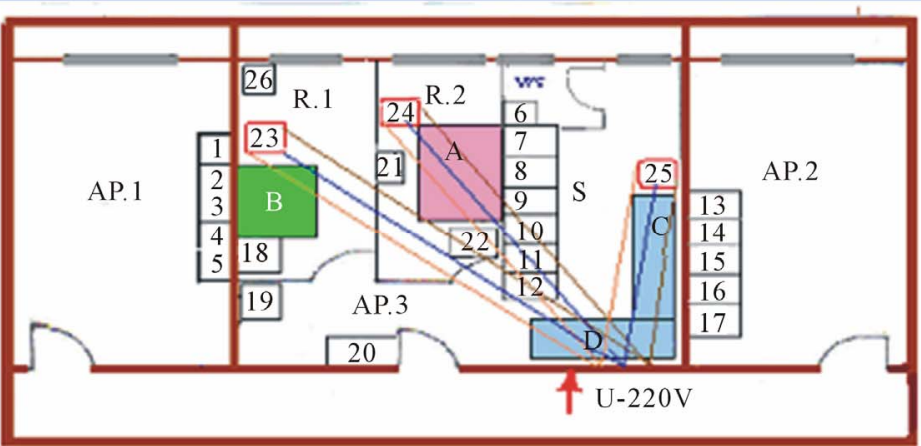

- AP.3-Apartment study object

- AP.1-Neighbouring apartment of study object

- AP.2-Neighbouring apartment of study object

- R.1-Room of apartment 3

- R.2-Room of apartment 3

- S-Living room of apartment 3

- A-Adults' bed

- B-Children’ bed

- C-Sofa

- D-Sofa

- $\mathrm{U}=220 \mathrm{~V}$-Entry voltage in apartment 3

- 1,7,17-Fridge

- 2,8,16-Mivrowave oven
- 3,9,15-Electric cooker

- 4,10,14-Kitchen Aspirator

- 5,11,13-Dishwasher

- 12-Fruit mixer and squeezer

- 6-Washing machine

- 18-Baby phone (transmitter)

- 22-Baby phone (receiver)

- 19-Computer set

- 20-Apartment intercom

- 23,24,25-Multi socket

- 21-Televison set

-26-Intemet antenna

Figure 1. The apartment AP.3 study object.

Table 1. Measure of the electric field intensity (E) and the magnetic induction (B) of some electronic devices and appliances.

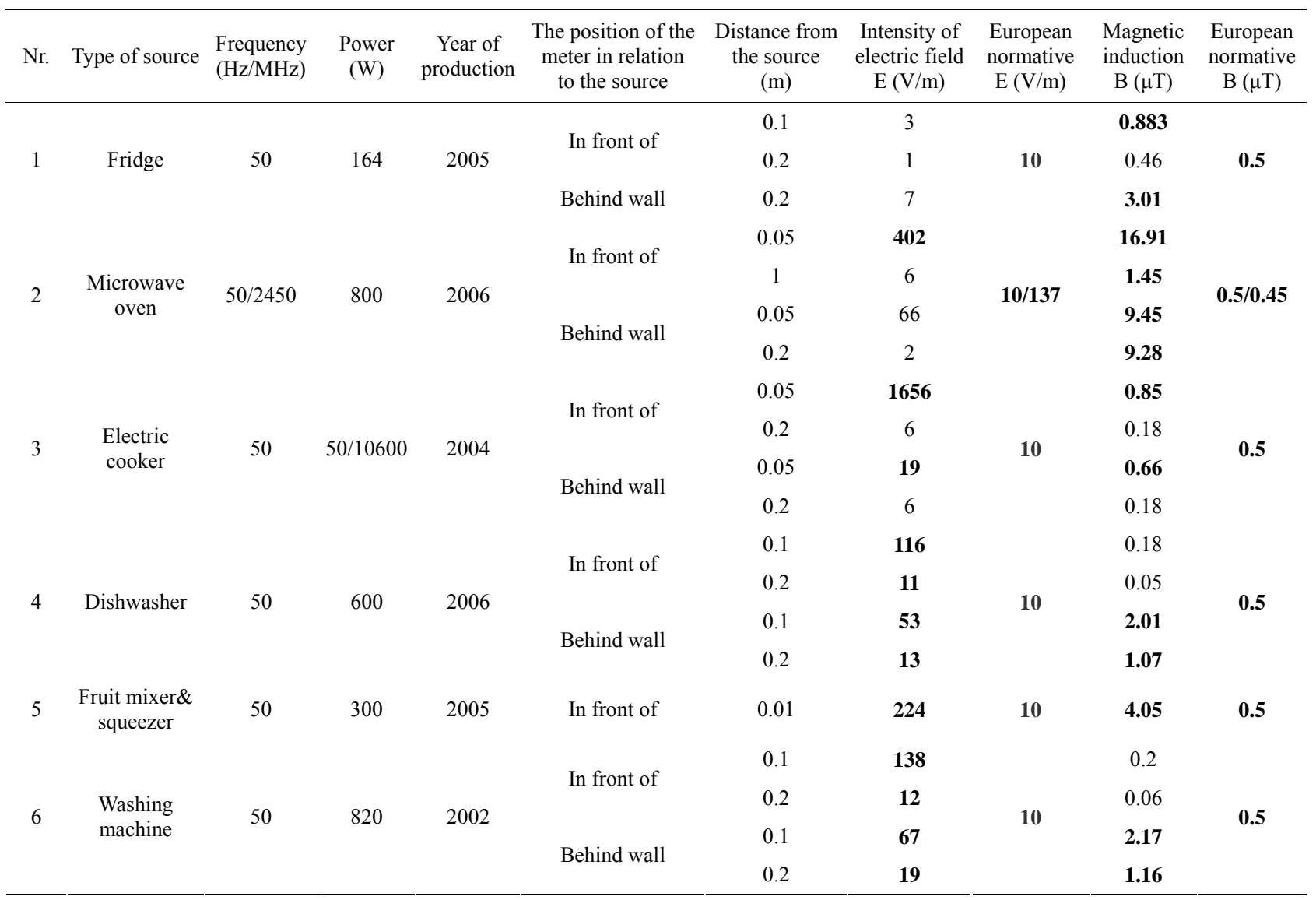




\section{Continued}

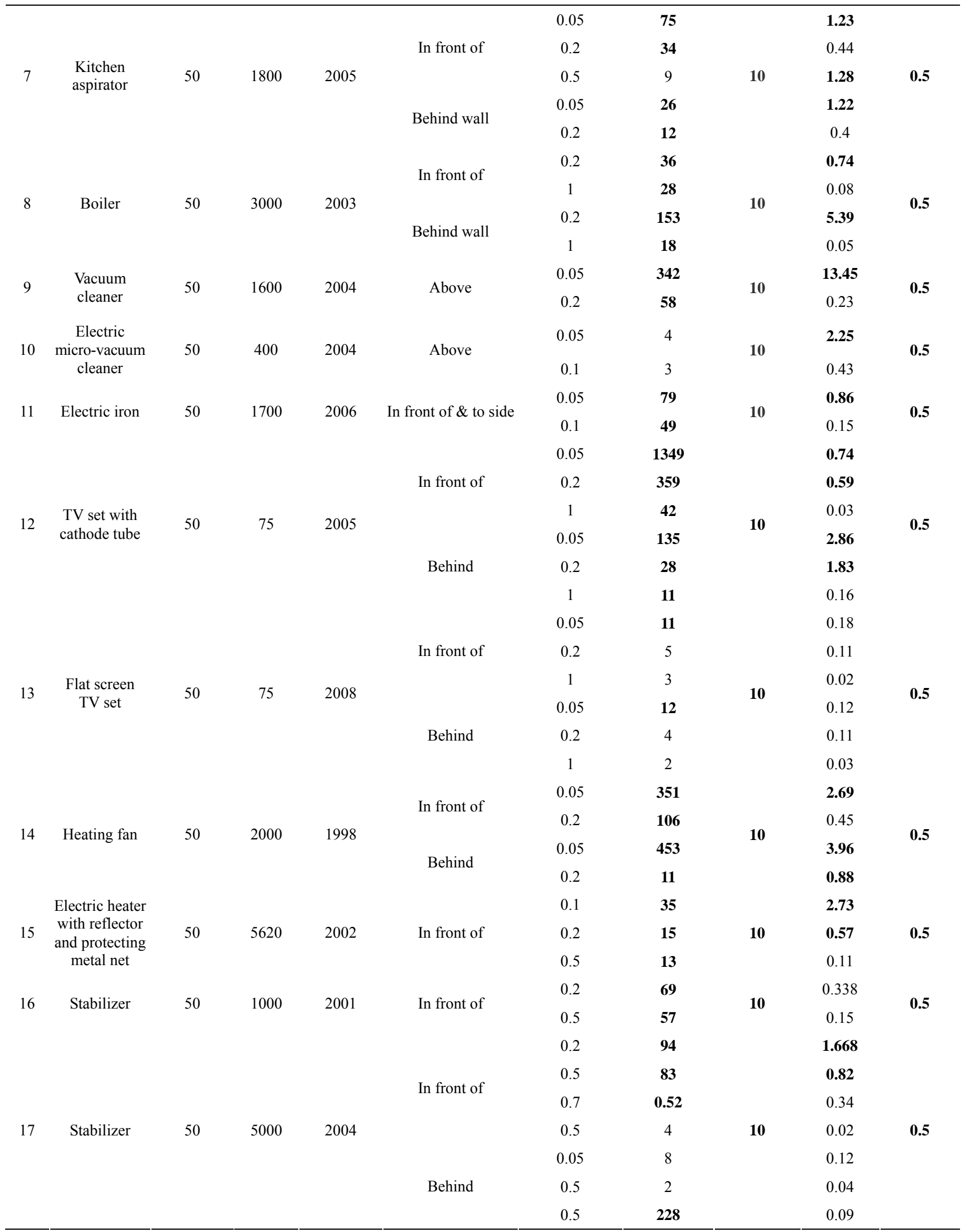

Note 1: The measurements on the microwave oven are done with frequency $2450 \mathrm{MHz}$ and the measurement on the electric cooker is done at the power 10600 $\mathrm{W}$; Note 2 : The apparatus inaccuracy $\pm 1 \%$ and our mistake $0.52 \%-1.3 \%$. 
Table 2. Measurements of the intensity of electric field (E) and the magnetic induction (B) of some electronic devices and appliances.

\begin{tabular}{|c|c|c|c|c|c|c|c|}
\hline Nr. & Type of source & $\begin{array}{l}\text { Frequency } \\
\quad(\mathrm{Hz})\end{array}$ & $\begin{array}{l}\text { Distance form } \\
\text { the source } \\
(\mathrm{m})\end{array}$ & $\begin{array}{c}\text { Intensity of } \\
\text { electric field } \\
E(V / m)\end{array}$ & $\begin{array}{l}\text { European } \\
\text { Normative } \\
\mathrm{E}(\mathrm{V} / \mathrm{m})\end{array}$ & $\begin{array}{c}\text { Magnetic } \\
\text { Induction } \\
\mathrm{B}(\mu \mathrm{T})\end{array}$ & $\begin{array}{c}\text { European } \\
\text { Normative } \\
\mathrm{B}(\mu \mathrm{T})\end{array}$ \\
\hline 1 & Box of fuse $220 \mathrm{~V}$ & 50 & $\begin{array}{l}0.1 \\
0.2\end{array}$ & $\begin{array}{c}199 \\
29\end{array}$ & 10 & $\begin{array}{l}2.03 \\
0.49\end{array}$ & 0.5 \\
\hline 2 & Apartment intercom & 50 & $\begin{array}{l}0.1 \\
0.2\end{array}$ & $\begin{array}{c}39 \\
4\end{array}$ & 10 & $\begin{array}{l}\mathbf{0 . 6 4} \\
0.26\end{array}$ & 0.5 \\
\hline 3 & $\begin{array}{l}\text { Screen and computer reserve battery } \\
220 \mathrm{~V}-19 \mathrm{~V} 3.16 \mathrm{~A}\end{array}$ & 50 & $\begin{array}{l}0.1 \\
0.2\end{array}$ & $\begin{array}{l}73 \\
13\end{array}$ & 10 & $\begin{array}{l}0.18 \\
0.06\end{array}$ & 0.5 \\
\hline 4 & Reading lamp & 50 & $\begin{array}{l}0.1 \\
0.2\end{array}$ & $\begin{array}{c}326 \\
55\end{array}$ & 10 & $\begin{array}{l}4.01 \\
0.37\end{array}$ & 0.5 \\
\hline 5 & Electric piano (organ) & 50 & $\begin{array}{l}0.1 \\
0.2\end{array}$ & $\begin{array}{c}103 \\
56\end{array}$ & 10 & $\begin{array}{l}\mathbf{0 . 6 7} \\
0.09\end{array}$ & 0.5 \\
\hline 6 & Electric pillow & 50 & 0.0 & 1779 & 10 & 0.05 & 0.5 \\
\hline 7 & Baby phone transmitter & 50 & $\begin{array}{c}0.1 \\
1\end{array}$ & $\begin{array}{c}91 \\
2\end{array}$ & 10 & $\begin{array}{l}0.24 \\
0.22\end{array}$ & 0.5 \\
\hline 8 & Baby phone-receiver & 50 & $\begin{array}{l}0.2 \\
1.2\end{array}$ & $\begin{array}{l}97 \\
15\end{array}$ & 10 & $\begin{array}{l}0.23 \\
0.14\end{array}$ & 0.5 \\
\hline 9 & Fax & 50 & 0.1 & 7 & 10 & 0.02 & 0.5 \\
\hline 10 & Cordless phone with fixed base ( when not ringing) & $2.4 \times 10^{9}$ & 0.05 & 48 & 137 & 0.14 & 0.45 \\
\hline 11 & Cordless phone with fixed base (when ringing) & $2.4 \times 10^{9}$ & 0.05 & 54 & 137 & 0.28 & 0.45 \\
\hline 12 & Cordless phone with fixed base reserve battery & 50 & $\begin{array}{c}0.05 \\
0.5\end{array}$ & $\begin{array}{c}11 \\
2\end{array}$ & 10 & $\begin{array}{l}3.62 \\
0.38\end{array}$ & 0.5 \\
\hline 13 & Internet aerial antenna (router) & $2.4 \times 10^{9}$ & $\begin{array}{c}0.2 \\
3\end{array}$ & $\begin{array}{l}11 \\
5\end{array}$ & 137 & $\begin{array}{c}0.24 \\
0.2\end{array}$ & 0.45 \\
\hline 14 & Internet Modem (cable connection) & 50 & $\begin{array}{c}0.05 \\
0.2\end{array}$ & $\begin{array}{c}11 \\
2\end{array}$ & 10 & $\begin{array}{c}0.28 \\
0.1\end{array}$ & 0.5 \\
\hline 15 & Mobile phone model 1992 & $1.8 \times 10^{9}$ & 0.01 & - & - & 0.627 & 0.45 \\
\hline 16 & Mobile phone model 2000 & $1.8 \times 10^{9}$ & 0.01 & - & - & 0.118 & 0.45 \\
\hline 17 & Mobile phone model 2005 & $1.8 \times 10^{9}$ & 0.01 & - & - & 0.012 & 0.45 \\
\hline 18 & Multiple socket $U=220 \mathrm{~V}$ & 50 & $\begin{array}{c}0.05 \\
0.2\end{array}$ & $\begin{array}{c}611 \\
31\end{array}$ & 10 & $\begin{array}{l}0.38 \\
\mathbf{0 . 6}\end{array}$ & 0.5 \\
\hline 19 & Electric line $220 \mathrm{~V}$ & 50 & 0.3 & 20 & 10 & 0.4 & 0.5 \\
\hline
\end{tabular}

Note: The apparatus inaccuracy $\pm 1 \%$ and our mistake $0.52 \%-1.3 \%$.

ence of the radiation level between new and old technology. The radiation level of the a flat screen TV set produced in 2008 with $75 \mathrm{~W}$ power is $0.56 \mu \mathrm{T}$ less than the one with cathode tube with the same $75 \mathrm{~W}$ power produced in 2005.

Table 2, the measurements 15, 16 and 17 show the difference in radiation levels of three mobile phones with different technology. The magnetic induction of the phone produced in 1992 was $0.667 \mu \mathrm{T}$ (the normative is 0.45 $\mu \mathrm{T}$ ), the one produced in 2000 had the magnetic induction $0.118 \mu \mathrm{T}$ and the one produced in 2005 had the magnetic induction $0.012 \mu \mathrm{T}$. The difference between the first and the last one is $0.615 \mu \mathrm{T}$.

Table 1, measurement 17 shows the use of a stabilizer with $5000 \mathrm{~W}$ power near a computer which at $0.2 \mathrm{~m}$ distance has a radiation of $\mathrm{B}=1.668 \mu \mathrm{T}(1.168 \mu \mathrm{T}$ above 
normative). Buying a stabilizer of this power is unnecessary. One with $1000 \mathrm{~W}$ or even less is sufficient. Another stabilizer of $1000 \mathrm{~W}$ (Table 1, measurement 16) was near a $\mathrm{TV}$ set which at a distance of $0.2 \mathrm{~m}$ had a radiation $\mathrm{B}=$ $0.338 \mu \mathrm{T}$. The position of the user was $0.5 \mathrm{~m}$ away from the $5000 \mathrm{~W}$ stabilizer and $5 \mathrm{~m}$ away from the $1000 \mathrm{~W}$ stabilizer.

The above mentioned stabilizers should have been in different positions and distances. The one with a higher power $(5000 \mathrm{~W})$ placed near the TV set should have been $5 \mathrm{~m}$ away from the viewer and the one with less power $(1000 \mathrm{~W})$ placed next to the computer should have been $0.5 \mathrm{~m}$ away. However such changes were not made due to lack of knowledge.

In Figure 1, several objects exposed in space and time are selected:

- The adult's bed A;

- The children's bed B;

- The sofa C;

- The sofa D.

The adult's bed $\mathrm{A}$ is exposed to radiation from:

1) The $220 \mathrm{~V}$ electric line which goes underneath it and according to measurement 19 , Table 2 , is $\mathrm{E}=20 \mathrm{~V} / \mathrm{m}$ and $\mathrm{B}=0.4 \mu \mathrm{T}$;

2) The baby phone (receiver), No. 22 in legend, according to measurement 8 , Table 2 , is $\mathrm{E}=97 \mathrm{~V} / \mathrm{m}$ and $\mathrm{B}$ $=0.23 \mu \mathrm{T}$;

3) The devices with legend numbers 6, 7, 8, 9, 10 placed behind the separating wall according to respective measurement 6, 1, 2, 3, 7, Table 1, are $\mathrm{E}=19 \mathrm{~V} / \mathrm{m}, \mathrm{B}=$ $1.16 \mu \mathrm{T} ; \mathrm{E}=7 \mathrm{~V} / \mathrm{m}, \mathrm{B}=3.01 \mu \mathrm{T} ; \mathrm{E}=2 \mathrm{~V} / \mathrm{m}, \mathrm{B}=9.28$ $\mu \mathrm{T} ; \mathrm{E}=6 \mathrm{~V} / \mathrm{m}, \mathrm{B}=0.18 \mu \mathrm{T} ; \mathrm{E}=12 \mathrm{~V} / \mathrm{m}, \mathrm{B}=0.4 \mu \mathrm{T}$.

The adults' bed should be next to the opposite wall in order to avoid this exposure, but it is not because of lack of knowledge.

The children's bed is exposed to the radiation of:

1) The $220 \mathrm{~V}$ electric line which goes underneath it and according to measurement 19, Table 2, is $\mathrm{E}=20$ $\mathrm{V} / \mathrm{m}$ and $\mathrm{B}=0.4 \mu \mathrm{T}$;

2) The multi socket with legend no.23 according to measurement 18 , Table 2 , is $\mathrm{E}=20 \mathrm{~V} / \mathrm{m}$ and $\mathrm{B}=0.4 \mu \mathrm{T}$;

3) The baby phone (transmitter) with legend no. 18 according to measurement 7, Table 2, is $\mathrm{E}=91 \mathrm{~V} / \mathrm{m}$ and $\mathrm{B}=0.24 \mu \mathrm{T}$;

4) The Internet antenna with legend no. 26 according to measurement 13, Table 2, is $\mathrm{E}=11 \mathrm{~V} / \mathrm{m}$ and $\mathrm{B}=0.2$ $\mu \mathrm{T}$ (while the respective normative are $137 \mathrm{~V} / \mathrm{m}$ and 0.45 $\mu \mathrm{T})$;

5) The devices of the neighbouring apartment (AP.1) with legend no. 1, 2, 3, 4, 5 placed behind the separating wall according to respective measurement 1, 2, 3, 7, Table 1 , are respectively $\mathrm{E}=7 \mathrm{~V} / \mathrm{m}, \mathrm{B}=3.01 \mu \mathrm{T} ; \mathrm{E}=2$ $\mathrm{V} / \mathrm{m}, \mathrm{B}=9.28 \mu \mathrm{T} ; \mathrm{E}=6 \mathrm{~V} / \mathrm{m}, \mathrm{B}=0.18 \mu \mathrm{T} ; \mathrm{E}=12 \mathrm{~V} / \mathrm{m}$, $\mathrm{B}=0.4 \mu \mathrm{T}$.
It was difficult to change the position of the children's bed because of the inappropriate house plan. Even when the inhabitants were told that they were exposed to the radiation of the devices in the neighbouring apartment, with legend no. 1, 2, 3, 4, they were indifferent and made no changes.

The best opportunity to prevent the bed from being exposed to the radiation emitted by these devices was available to the architect of the building, who should have taken into consideration the opposite wall (AP.1) when planning the layout of the building.

The children's bed could be protected from the internet antenna radiation, with legend no. 26 , if the signal from the modem to the computer, with legend No. 18, were done with a cable.

The sofa $\mathrm{C}$ is exposed to the radiation from:

1) The multi socket with legend no. 25 according to measurement 18 , Table 2 , is $\mathrm{E}=31 \mathrm{~V} / \mathrm{m}$ and $\mathrm{B}=0.6 \mu \mathrm{T}$;

2) The devices in the neighbouring apartment (AP.2) with legend no. 13, 14, 15, 16, 17, placed behind the separating wall, according to respective measurements 4 , 7, 3, 2, 1, Table 1 , is respectively $\mathrm{E}=13 \mathrm{~V} / \mathrm{m}, \mathrm{B}=1.07$ $\mu \mathrm{T} ; \mathrm{E}=12 \mathrm{~V} / \mathrm{m}, \mathrm{B}=0.4 \mu \mathrm{T} ; \mathrm{E}=6 \mathrm{~V} / \mathrm{m}, \mathrm{B}=0.18 \mu \mathrm{T} ; \mathrm{E}$ $=2 \mathrm{~V} / \mathrm{m}, \mathrm{B}=9.28 \mu \mathrm{T} ; \mathrm{E}=7 \mathrm{~V} / \mathrm{m}, \mathrm{B}=3.01 \mu \mathrm{T}$;

The sofa $\mathrm{D}$ is exposed to the radiation of:

1) The devices of the neighbouring apartment (AP.1) with legend no. 17 according to measurement 1, Table 1, is $\mathrm{E}=7 \mathrm{~V} / \mathrm{m}, \mathrm{B}=3.01 \mu \mathrm{T}$;

2) The electric fuse box of voltage $U=220 \mathrm{~V}$ according to measurement 1, Table 2, the intensity of the electric field (E) varies between $29 \mathrm{~V} / \mathrm{m}$ and $199 \mathrm{~V} / \mathrm{m}$ and the magnetic induction (B) varies between $0.49 \mu \mathrm{T}$ and 2.03 $\mu \mathrm{T}$.

The living room where the sofas C \& D are placed has no other possibility for the furnishing. Again it was the responsibility of the architect to plan, beginning in his design project, the electric devices $13,14,15,16,17$ on the wall opposite the apartment and the fuse box next to the apartment intercom with legend no. 20.

\section{CONCLUSIONS}

Based on the above measurements we can draw the respective conclusions:

1) The less electronic apparatus and appliances an environment has, the less a person is endangered by nonionizing radiation.

2) The passing of the electric lines should be placed away from areas which the inhabitants stay for long periods of time (such as places for beds, sofas etc)

3) The producers of electronic apparatus and appliances should raise the security coefficient towards nonionizing radiation and the users should be careful to replace over time apparatus of old technology with those of 
new technology.

4) The sources of non-ionizing radiation should be placed as far away as possible from areas which the inhabitants stay for long periods of time.

5) Apparatus with low power should be chosen as much as possible.

6) The users of electronic equipment and appliances should decrease as much as possible the exposure time during work.

7) The inhabitants, while furnishing their houses, should pay attention to the sources of non-ionizing radiation in their homes as well as in neighbouring houses.

The architects should "arrange the relation to" nonionizing radiation while planning dwelling places.

\section{REFERENCES}

[1] Griffiths, D.J. (1989) Introduction to electrodynamics. 2nd Edition, Prentice-Hall, London.

[2] Krane, K. (1996) Modern physics. 2nd Edition, Oregon University, Eugene.

[3] Varocos, P. and Aleksandropullos, K. (1995) The physics of the solid body. Publishing House Savalla, Athinë.

[4] Llukas, M.H. (2011) Useful tips to minimize exposure to electromagnetic radiation from Luke. University of Athens, Athens.

http://kyttariki.biol.uoa.gr/EMR-GROUP/emr-suggestions. $\underline{\mathrm{htm}}$

[5] Non-Ionizing Radiation, January 2004, http://www.physics4.gr/faq/radiationcells 1.html

[6] Ksanthi, P. and Konstandina, N. (2004) Application of computer techniques for the study of mobile phones and basic systems of this phone. Polytechnic University, Athens.

[7] Institute of Electrical and Electronics Engineers (IEEE) (2006) standard C95.1-2005. Non-Ionizing radiation standards.

http://www-group.slac.stanford.edu/esh/hazardous substa nces/nir/p_standards.htm

[8] ICNIRP. (1998) ICNIRP guidelines for limiting exposure to time-varying electric, magnetic and electromagnetic fields (up to 300GHZ) ICNIRP standard. Health Physics, 74, 494-522. http://www.icnirp.de/documents/emfgdl.pdf

[9] Mobile Telephone Communication Antennas and Health Effects. (2012).

http://www.arpansa.gov.au/radiationprotection/factsheets/ is antenna.cfm

[10] Official Journal of European Union (2004) Directive 2004/40/EC of the European Parliament and of the Council of 29 April 2004. 